\title{
REWARDING A LIVING KIDNEY DONOR: A COMPARISON BETWEEN SOUTH AFRICA, SINGAPORE AND IRAN ${ }^{*}$
}

\author{
B Venter \\ LLB LLM \\ Lecturer, Department of Jurisprudence, UNISA
}

M Slabbert

BA BA(Hons) HED BProc LLB LLD

Professor, Department of Jurisprudence, UNISA

\section{SUMMARY}

There are thousands of desperate people globally who need a kidney for transplantation. The number of people who require a kidney transplant continues to escalate faster than the number of kidneys available for a transplant. If South Africa wants to improve its current kidney-donation rate it should seek guidance from abroad. This article will compare South African transplant legislation with current legislation in Singapore and Iran. These two countries are of significance to the transplant debate as Singapore has recently legalized the reimbursement of costs of the organ donor while Iran goes a step further and pays the kidney donor. In conclusion it is argued that South Africa could learn from these two countries in order to try and address the shortage of transplantable organs locally.

\section{$1 \quad$ INTRODUCTION}

Kidney transplantation refers to a surgical operation where a kidney is taken from a healthy person's body (also known as the "kidney donor") and is placed into a patient's body (known as the "organ recipient") while both live afterwards. ${ }^{1}$ The objective of a kidney transplantation is to restore a

This article is an extract from and an adaptation of B Venter's LLM dissertation entitled $A$ Selection of Constitutional Perspectives on Human Kidney Sale (UNISA 2012).

Living with a single normal kidney is possible without any extreme complications. Most people with a single kidney still have a normal life with no problems. Any decrease in kidney function is usually mild. A study was done where kidney donors between the ages of 20 and 37 were observed. Most of them had normal functions and most problems were the same as for people of the same age with two kidneys. Long-term risks to a kidney donor are small. With consideration to the surgery, the harm is also minimal; after the removal of the kidney the donor may be in pain for a few weeks but that is all. This pain may also be less if surgery is done through laparoscopy (a small cut). Griffith "Living With One Kidney" (no date) www.myoptumhealth.com (accessed 2012-04-08). 
meaningful life to a patient who was doomed to a premature death due to a fatal disease of a vital organ. ${ }^{2}$ Other life-extending measures such as dialysis, substantially lower the quality of life for the patient, ${ }^{3}$ while a successful organ transplant dramatically restores health.

Organ transplantations are probably one of the twentieth century's most miraculous medical breakthroughs. Decades ago the thought of removing a person's kidney and placing it into a patients' body, while keeping both alive, seemed almost impossible. In the early 1950s there were several experiments with organ transplants in Paris, France and Boston in the United States of America, but all of these experiments failed miserably due to the fact that no immunosuppressant ${ }^{4}$ was available. ${ }^{5}$ Yet, in 1954 a report by Dr Joseph Murray and Dr John Merrill at the Bent Brigham Hospital in Boston documented the first successful kidney transplant between living identical twin brothers. ${ }^{6}$ The recipient of the kidney survived for eight years with no evidence of rejection. Today, kidney transplants have transformed from what was initially a clinical experiment to a routine and reliable practice that has saved thousands of lives.

The first successful kidney transplant that took place in South Africa was performed by Dr Christiaan Barnard in October 1967, and two months later he performed the first heart transplant in the Groote Schuur Hospital in Cape Town. ${ }^{7}$ These transplants did not catch South African legislators totally unaware as the Post Mortem Examinations and Removal of Tissue Act 30 of 1952 was already promulgated. It was an advanced measure at the time, since the Act laid down a basis for all transplant procedures. In this regard South Africa was more advanced than some of the more developed

2 The vital organs are kidneys, lungs, the heart and the liver. This article focuses on kidneys only. Only a kidney can be removed from a living person which will not result in death. (A part of a person's liver can also be donated by a living donor but it is not yet common practice in South Africa). Hakim Introduction To Organ Transplantation (1997) 2.

3 Haemodialysis is a treatment that removes the waste products and excess fluid gathered in the blood and body tissue as a result of kidney failure. The blood is filtered outside the body by means of a dialyser during three or four treatment sessions that can last between three to five hours each week. Dialysis can cost up to R200 000 per annum per patient in the private sector whereas the costs of a kidney transplantation is R250 000 including the ImmunoPro Rx medication that must be taken for the first three months. After the procedure, the costs of maintaining a kidney transplant is approximately R100 000 per annum. Harillall and Kasiram "Exploring the Bio-Psychological Effect of Renal Replacement Therapy Amongst Patients in a State Hospital in South Africa" 201116 Health SA Gesondheid 5; and Anonymous http://www.discovery.co.za (no date) (accessed 2011-0816).

4 Immunosuppressant therapy works by curbing the production and activity of lymphocytes. It has been used since the middle of the previous century to prevent the human body from rejecting transplanted organs. Anti-immune drugs may raise the chances of survival of a transplanted organ, but they also render a patient more vulnerable to other infections. An organ can still be rejected in spite of immunosuppressive therapy. Norval Defining Moments: Marius Barnard - An Autobiography (2011) 177.

5 lbid.

6 Linden "History of Solid Organ Transplantation and Organ Donation" 200925 Critical Care Clinics 167.

7 Cape Gateway "Chris Barnard Performs World's First Heart Transplant" http://www.westerncape.gov.za/eng/pubs/public_info/C/99478 May 2010 (accessed 201201-10). 
countries such as Belgium, Holland, Austria, Western Germany, Japan and Switzerland, which had no transplant legislation. ${ }^{8}$

Since the 1952 Act, South Africa has had three more major enacted statutes that specifically deal with the regulation of the anatomical removal of tissue. ${ }^{9}$ These statutes are the Anatomical Donations and Post Mortem Examinations Act 24 of 1970, the Human Tissue Act 65 of $1983^{10}$ and the current National Health Act 61 of 2003. ${ }^{11}$

All the previous Acts had more or less the same purpose regarding organ transplants. The Anatomical Donations and Post Mortem Examinations Act came into force on 9 March 1970 and repealed all previous legislation. This Act was the result of intensive study of legislation in other leading countries and it also considered South African practices and attitudes. ${ }^{12}$ The Act settled a number of issues at the time and had a broader scope, allowing for the donation of eye tissue (whereas the 1952 Act had strict provisions regarding this matter). The Act mainly provided for the donation of human bodies and tissue for therapeutic or scientific purposes, and for the removal of such tissue and their use in living persons. ${ }^{3}$ The Act was framed to facilitate the acquisition and use of tissue, at the same time ensuring that the interests of the public are safeguarded. The Anatomical Donations and Post Mortem Examinations Act was later replaced by the Human Tissue Act 65 of 1983. The Human Tissue Act provided a long-standing regulatory framework regarding organ transplants in the country. The National Health Act of 2003 repealed the Human Tissue Act and all other previous health-related legislation, and established a single framework for the regulation of organ procurement and transplantation.

A few decades ago, South African transplant legislation could have been compared with other leading countries. Strauss even stated that the Anatomical Donations and Post Mortem Examinations Act was rated as one of the most progressive measures of its kind in the world in $1970 .{ }^{15}$ This is no longer the case and after all these years, South African transplant legislation is still in a developing phase.

This article will compare South African transplant legislation with current legislation in Singapore and Iran. These two countries are of significance to the transplant debate as Singapore has recently legalized the reimbursement of costs of the organ donor while Iran goes a step further and pays the kidney donor. In conclusion it is argued that South Africa could learn from

\footnotetext{
Strauss "The New Legislation on Tissue and Organ Transplantation" 1970 SAMJ 803.

9 Fourie "An Analysis of the Doctrine of Presumed Consent and the Principles of Required Response and Required Request in Organ Procurement" LLM dissertation (University of Pretoria 2006) 111.

10 Hereinafter "the Human Tissue Act".

11 Hereinafter "the National Health Act".

2 See Strauss 1970 SAMJ 807.

13 Cooper, De Villiers, Smith, Crombie, Boyd, Jacobson and Barnard "Medical, Legal and Administrative Aspects of Cadaveric Organ Donations in the RSA" 198262 SAMJ 936.

14 Chapter 8 of the National Health Act contains ss 53-68, which deal with the control of the use of blood, blood products, tissues and gametes in humans. Proc R18 in GG 35081 of 2012-02-27.

15 See Strauss 1970 SAMJ 803.
} 
these two countries in order to try an address the shortage of transplantable organs locally.

\section{ORGAN-PROCUREMENT SYSTEMS AND ORGAN SHORTAGES}

Internationally, two main organ-procurement systems are acknowledged: an "opting-in" system and an "opting-out" system. The opting-in system is a voluntary and altruistic system. According to this system a person has to give explicit informed consent before his death, confirming that he wants to donate his organs. ${ }^{16}$ Countries that follow the opting-in system include South Africa, ${ }^{17}$ Iran, the United Kingdom and the United States of America. ${ }^{18}$ In contrast with the opting-in procurement system is the opting-out system. According to this system everyone is a potential organ donor unless the person has registered before death that he does not want to be an organ donor. ${ }^{19}$ Countries that follow the opting-out system generally have a higher success rate. These countries include Singapore, Spain, Belgium and France. $^{20}$

The procurement system that is followed in a country plays a very vital role in that country's success rate in acquiring organs for donation. To use only cadaveric organs for transplantation would be ideal, but unfortunately the donor rate is very low. Singapore has about nine deceased donors per million of the population, ${ }^{21}$ while Iran has 2.4 deceased $^{22}$ donors per million of the population. ${ }^{23}$ The method of acquiring donated organs could also be the reason why a country like Spain has approximately 34 deceased donors per million population, ${ }^{24}$ compared to South Africa with a disappointing 45000 people who have indicated a willingness to be organ donors, which is

16 Schicktanz, Wiesermann and Wöhlke Teaching Ethics in Organ Transplantation and Tissue Donation (2010) 6.

17 If a person decides to become an organ donor in South Africa he is not placed on any list. A person can indicate his wish to become an organ donor to the Organ Donor Foundation. Once this is done, the donor will receive a card and two stickers for his identification document and driver's licence, to indicate that he is a donor. Organ Donor Foundation (no date) http:www.odf.org.za (accessed 2011-08-17).

18 Hartwell "Global Organ Donation Policies Around the World" August 2010 www.lorihartwell.com?GlobalOrganDonationPolices (accessed 2011-08-18).

19 See Schicktanz et al Teaching Ethics in Organ Transplantation and Tissue Donation 7.

20 www.lorihartwell.com?GlobalOrganDonationPolices (accessed 2011-08-18).

21 Kwek, Lew, Tan and Kong "The Transplantable Organ Shortage in Singapore - Has Implementation of Presumed Consent to Organ Donation Made a Difference?" 200938 PubMed 346.

22 It should be mentioned that even though Iran has a low deceased-donor rate, they have a success rate of 26 per million of the population regarding renal transplants, and in 2009 approximately 1615 renal transplants took place. Horvat, Salimah and Garg "Global Trends in the Rates of Living Kidney Donation Rates in Living Kidney Donation" 200975 Kidney International 1088.

23 Thomas and Klapdor "The Future of Organ Donation in Australia: Moving Beyond the 'Gift of Life"' October 2008 http://aph.gov.au/library/pubs/rp/2008-09/09rp11.htm (accessed 2011-08-19).

24 Wong "Spain Leads The Way in Organ Donation" June 2009 articles.cnn.com/2009-0617/health/organ.donation_1_organ-donation-donation-rates-number-of-organdonors?_s=P M:HEALTH (accessed 2011-08-19). 
less than $0,1 \%$ of the population. ${ }^{25}$ It should be noted, though, that the South African statistics are estimates, since there is no national register where people indicate their willingness to donate organs. The donors referred to are only those people who have got in touch with the Organ Donor Foundation indicating that they were willing to donate their organs. There are no records of those who have indicated a willingness to donate and those who eventually did donate their organs. A way to curb the ever-increasing demand for kidneys is to use living donors. The problem is that a donor giving up a kidney has to do it altruistically. In South Africa living kidney donations can be done by a related or unrelated person. If a person is unrelated ministerial permission must be obtained for the transplantation. Currently, the donor is the only person involved in the transplant process who does not receive a benefit. The recipient receives a kidney and his quality of life is increased; the medical practitioners involved receive remuneration for their services; but the donor - who in reality offers up a kidney - does not receive any benefit. South Africa needs to perform at least a 1000 kidney transplants per year but only approximately 250 kidney transplants are performed due to the acute shortage. ${ }^{26}$

\section{CURRENT REGULATION OF KIDNEY TRANS- PLANTS IN SOUTH AFRICA}

Kidney transplants in South Africa are currently controlled by the National Health Act of 2003, as well as the Regulations in terms thereof. ${ }^{27}$ The Act governs the removal of tissue, blood or gametes from the bodies of living and dead persons for therapeutic and other uses, as well as the donation of human bodies.

\section{The National Health Act}

Section 56 of the National Health Act mainly regulates the position regarding the use of tissue harvested from living persons. "Tissue" is described in the Act as "human tissue, and includes flesh, bone, a gland, an organ, skin, bone marrow or body fluid, but excludes blood or a gamete". ${ }^{28}$ The donation of tissue that is not replaceable by natural processes is more strictly controlled than tissue that is replaceable by natural processes. Section 56(1) of the Act stipulates that tissue may only be withdrawn from a living person for medical or dental purposes, as prescribed.

One of the most important requirements for a lawful kidney transplant is that the potential kidney donor must have given written informed consent. ${ }^{29}$ Tissue that is not replaceable by natural processes, such as kidneys, may not be harvested from a person younger than 18 years old even if there is

25 Organ Donor Foundation (no date) www.odf.org.za (accessed 2011-08-15).

Organ Donor Foundation (no date) www.odf.org.za (accessed 2012-07-04).

27 Currently, there are no specific regulations for transplants published, yet these regulations are still under discussion between role-players such as the government and the South African Transplant Society.

28 A gamete is defined as either of the two generative cells essential for human reproduction.

29 S 55(1)(a). 
consent from the parents ${ }^{30}$ and under no circumstances may tissue be removed from a person who is mentally ill within the meaning of the Mental Health Care Act. Thus, a kidney may not be removed from the living body of a person that can be defined as mentally ill by the Mental Health Care Act 17 of $2002 .^{31}$

It should be mentioned that the Minister may authorize the removal or withdrawal of tissue and he may also impose any condition that may be necessary in respect of such removal or withdrawal. ${ }^{32}$

Section 60 of the Act imposes a strict limitation: remuneration may not be received for any donation. All donations are regarded as a "gift of life" and it will be an offence if a person who has donated a kidney receives any form of financial or other reward for such a donation. ${ }^{33}$ However, section 60(4)(a) of the Act stipulates that a donor may receive reimbursement of reasonable costs incurred by him to provide such a donation, but neither the Act nor the Regulations ${ }^{34}$ or the draft regulations $\mathrm{s}^{35}$ determine who will be liable for these costs or what exactly "reasonable costs" entail. Any person who violates the Act is liable on conviction to a fine or to imprisonment for a period not exceeding five years or to both a fine and imprisonment. ${ }^{36}$

\section{A MICRO-COMPARISON WITH THE TRANSPLANT LEGISLATION OF SINGAPORE AND IRAN}

If one was to draw a comparison between certain countries in terms of the number of kidney donations, the difference is startling. For instance, South Africa averages only 9,2 kidney donations per one million people, ${ }^{37}$ whereas a country such as Iran, which allows payment for living-donor kidneys and has one of the most successful kidney transplant programmes in its region, boasts with 28 kidney donations per one million people. ${ }^{38}$ It is a reality that the need for viable donor kidneys just keeps on increasing while the supply of viable donor kidneys has almost stagnated or decreased in the majority of countries. These statistics illustrate that South Africa has to take extreme measures to improve its number of kidney-donations. Consequently, if South Africa wants to improve its current kidney donation rate it should seek guidance from abroad.

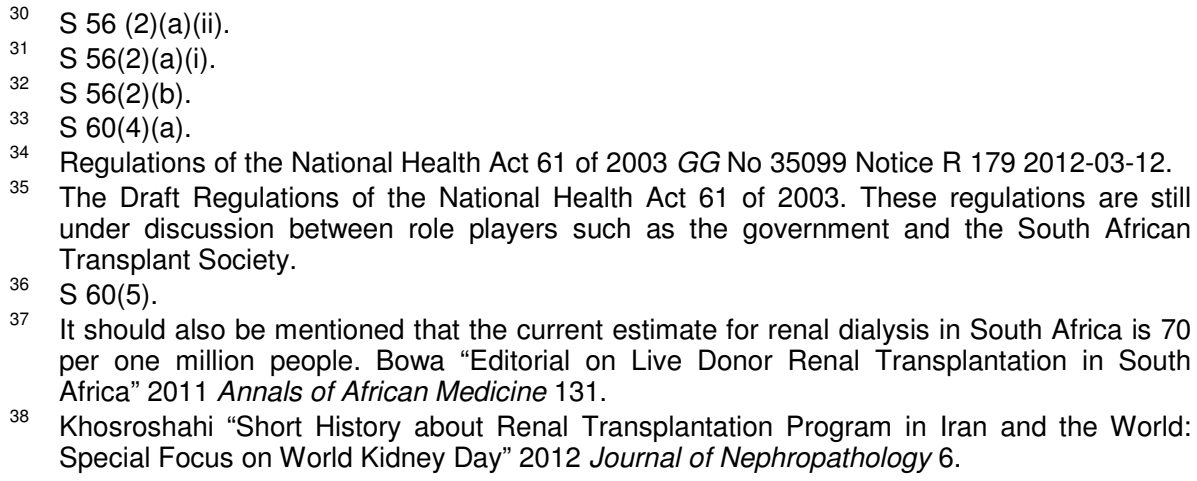

${ }^{37}$ It should also be mentioned that the current estimate for renal dialysis in South Africa is 70 per one million people. Bowa "Editorial on Live Donor Renal Transplantation in South Africa" 2011 Annals of African Medicine 131.

38 Khosroshahi "Short History about Renal Transplantation Program in Iran and the World: Special Focus on World Kidney Day" 2012 Journal of Nephropathology 6. 


\section{Singapore and kidney donations}

The Republic of Singapore is a city, state and country all in one; situated at the southernmost tip of the Malay Peninsula, and has a population of approximately 5,8 million people. ${ }^{39}$ Just as South Africa boasts with the fact that its cultures represent a rainbow nation, Singapore is also a melting pot of cultures, which include Malay, Chinese, Indian and European people. The diversity in culture leads to a whole range of religions, such as Buddhist, Taoist, Christian, Muslim and Hindu. South Africa and Singapore share a number of similarities, but there is one main aspect that separates them Singapore is a developed country whereas South Africa is a developing country.

Singapore performed its first kidney transplant in 1970. At that time, their kidney donations were still based on a voluntary system. ${ }^{40}$ Singapore enjoyed great success with kidney transplants during that era, but the number of kidney donations was insufficient due to the fact that kidneys were harvested from individuals who voluntary agreed to be kidney donors. From 1970 to 1988 , only 85 deceased kidney transplants occurred. ${ }^{41}$ In June 1987 , in an effort to remedy the kidney shortage, Singapore adopted the Human Organ Transplant Act. ${ }^{42}$ The HOTA and the various amendment acts that followed had an immense impact on Singapore's kidney donations.

\section{The HOTA and presumed consent}

Singapore follows a system of "opting out". This system is one of the biggest changes that were brought on by the HOTA to improve the organ shortage. As previously indicated in terms of the opting-out system everyone is regarded as an organ donor unless he/she explicitly revokes the consent. Thus, if a person does not revoke his consent by registering his objection with the Director of Medical Services, ${ }^{43}$ he will be regarded as an organ donor. $^{44}$

When the HOTA was first implemented in Singapore, section 5(2)(a) to (e) stipulated that all Singapore citizens and permanent residents, excluding Muslims, who were between the ages of 21 and 60 years old and of sound mind would be regarded as organ donors. The Amendment Act of 2008 that was implemented on 1 August 2008 further changed the position. The

39 Heng "Singapore's Population Hits 5.18 Million as at End June" July 2011 www.stratstimes.com/Breakingnews (accessed 2012-04-25).

40 Fitzgibbons "Cadaveric Organ Donation and Consent: A Comparative Analysis of the United States, Japan and China" 1999 Journal of International and Comparative Law 93.

41 Vathsala and Khuan "Renal Transplantation in Singapore" 200938 Annals Academy of Medical Singapore 292.

42 Human Organ Transplant Act of 1987 (hereinafter "HOTA"). See Fitzgibbons 1999 Journal of International and Comparative Law 93.

43 S 5(2)(a) of the Human Organ Transplant (Amendment) Act 2008.

44 Slabbert and Oosthuizen "Establishing a Market for Human Organs in South Africa: Part 1: A Proposal” 200728 Obiter 45. 
"opting-out" system then included all Muslim residents, and if a Muslim did not want to be an organ donor he would have to revoke his consent. ${ }^{45}$

One year later, the Amendment Act of 2009 changed the position once again, and the 60 -year and older age limit was removed. ${ }^{46}$ Presently, section $5(2)$ (a) to (e) of the HOTA stipulates that all Singapore citizens and permanent residents over the age of 21 years who are of sound mind will be regarded as organ donors unless a person explicitly revokes his consent. The introduction of the opting-out system led to an increase of kidney transplants between 1988 and 2004 - 664 deceased-donor kidney transplants were performed, yielding an average of 41,4 deceased-donor kidney transplants yearly. ${ }^{47}$

There was also a slight increase in living-donor kidney transplants. A total of 233 kidney transplants were performed, yielding an average of 14 livingdonor kidney transplants yearly. ${ }^{48}$ It must be borne in mind that a livingdonor kidney transplant has a much higher success rate and is more beneficial for the kidney recipient. ${ }^{49}$ Kidney-transplant rates progressively started to decrease from 2004, and the HOTA had to be amended once again to ensure more kidney transplants. The Amendment Act of 2009 initiated the reimbursement of living donors in accordance with international and local ethical practices. ${ }^{50}$

\section{The HOTA and the reimbursement of living donors}

In Singapore, almost 300 patients suffer from end-stage renal failure yearly. The country has the fifth highest incidence of kidney failure in the world, with $20,1 \%$ Singaporeans suffering from hypertension, and an additional 8,2\% suffering from diabetes. ${ }^{51}$ Singapore's first attempt to increase its kidneydonation rates was to change its voluntary system to a presumed consent system. The change of an organ-procurement system, however, did not have an immense effect on living-donor kidney transplants. Consequently, it was decided that more serious steps needed to be taken in order to increase the number of living-donor kidneys - the reimbursement of living kidney donors, as stipulated in the HOTA Amendment Act of 2009. Section 14(3)(c)(ii) states that the donor may be reimbursed for the following costs or expenses (including the costs of travel, accommodation, domestic help or child care) or loss of earnings as far as are reasonably or directly attributable

\footnotetext{
The Human Organ Transplant (Amendment) Act 2008.

The Human Organ Transplant (Amendment) Act 2009.

See Vathsala and Khuan 200938 Annals Academy of Medical Singapore 293.

See Vathsala and Khuan 200938 Annals Academy of Medical Singapore 292.

49 Short- and long-term survival rates are significantly better for transplants from living donors than transplants from deceased donors. On average, approximately 18 years for a kidney from a living donor compared to 13 years for a kidney from a deceased donor. Furthermore living-donor kidneys almost always start functioning immediately, whereas a deceaseddonor kidney can take a few days to a few weeks to start functioning. Living Kidney Donor Network "Benefits of Living Donation" (no date) www.lkdn.org/benefits_living_donation.htm (accessed 2012-07-03)

50 Human Organ Transplant (Amendment) Act 2009.

51 National Kidney Foundation "Haemodialysis" January 2009 http://www.nkfs.org (accessed 2012-04-27).
} 
to the donor supplying his kidney. ${ }^{52}$ Section 14(3) (c)(iii) stipulates that the donor will be reimbursed for any short-term or long-term medical care or insurance protection that may be reasonably necessary as a consequence of the donor supplying his kidney. ${ }^{53}$

Before the Amendment of the HOTA, payment of any kind to an organ donor was prohibited. Thus, the implementation of reimbursement for the living-kidney donor sparked a lot of controversy under the Singaporeans. Critics of the reimbursement had two main concerns: Firstly, they were concerned that the reimbursement may open the "back door" to organ trading. ${ }^{54}$ The Amendment Act of 2009 , however, prevented the increase in organ trading by increasing the penalties for organ-trading syndicates and middlemen. ${ }^{55}$ Secondly, there was the concern that the reimbursement lacks caps and detailed formulae for assessing losses. The Minister of Health was of the opinion that he preferred not to make the Act too technical, as he wanted to prevent the reimbursement from turning into an inducement. ${ }^{56} \mathrm{He}$ decided that an inducement could be prevented as long as the amount of reimbursement was not too high. The government's view was that the reimbursement of verifiable and reasonable expenses of the kidney transplant could not constitute a payment for a kidney, and that it should rather be viewed as part of the legitimate costs of treating the patient. ${ }^{57}$

The government also mentioned that the reimbursement to donors actually "rights a wrong". The HOTA then took a further step in terms of the Act's vagueness, and instated a hospital-ethics committee requirement. According to section 15B (2) of the HOTA, every transplant-ethics committee will consist of not fewer than three persons, of whom at least one shall be a medical practitioner with no connection to the hospital, and one shall be a lay person. The purpose of the transplant-ethics committee is to assess and give its written authorization for a living kidney transplant to be carried out. ${ }^{58}$ The transplant-ethics committee plays a very important role when it comes to verifying that the donor is not being coerced, financially induced or emotionally pressured. ${ }^{59}$ The transplant-ethics committees work according to guidelines, and the members of the committee have to undergo training in medical ethics and they are subjected to close regular audits. ${ }^{60}$

The reimbursements of kidney transplants are primarily done by the organ recipients. According to the Minister of Health, the issues of equity are addressed by having the rich subsidize the poor in obtaining their kidneys. The National Kidney Foundation also launched a \$10-million kidney livingdonor support fund in November 2009 to provide financial assistance to live

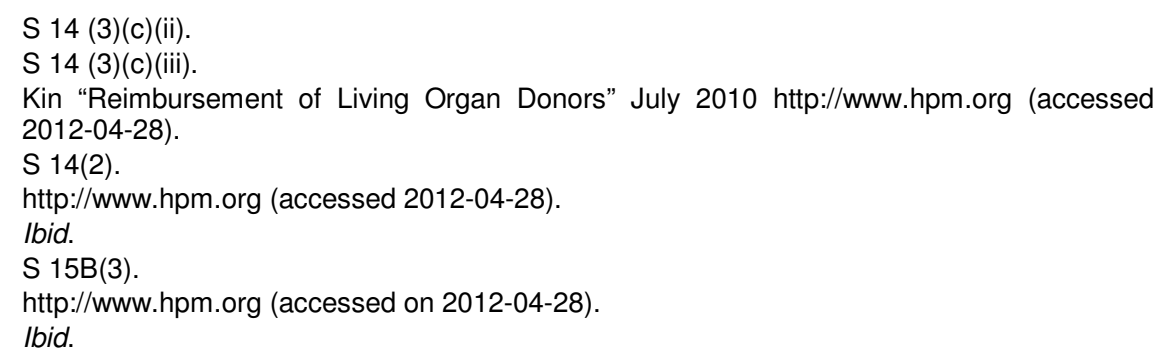


kidney donors. ${ }^{61}$ By April 2010, the National Kidney Fund had already reimbursed five kidney donors for their medical expenses and loss of income from donating a kidney. ${ }^{62}$ Additional voluntary welfare organizations have also expressed interest in giving ad hoc financial assistance. ${ }^{63}$ Singapore currently has approximately 22 kidney donations per one million people. Their rates are higher than those of surrounding areas such as Malaysia $(4,5$ kidney donations per one million people), Philippines (8 kidney donations per one million people) or Hong Kong (9,6 kidney donations per one million people). ${ }^{64}$ The statistics are a clear indication that Singapore's legislative initiatives have increased their living-donor kidney-transplant rates.

South Africa has a lack of constitutional guidance and case law regarding kidney donations. The Constitution states that South Africa may seek guidance from foreign law, ${ }^{65}$ and thus Singapore could be a perfect example to follow due to the cultural and religious similarities of South Africa and Singapore. The National Health Act already stipulates in section 60(4)(a) that the donor may be reimbursed for the reasonable costs incurred by him to provide an organ. However, in South Africa it has not yet been decided what will be regarded as reasonable costs and who will be responsible for these reasonable costs. South African legislators could take a look at section 14(3)(c)(ii) and (iii) of the HOTA and also reimburse kidney donors for direct expenses incurred as a result of the donation, such as transport and accommodation, as well as indirect expenses, such as loss of earnings and future expenses for the costs of long-term care of the donor and all medical follow-up costs. Furthermore South African legislators could also seek guidance from the Declaration of Istanbul on Organ Trafficking and Transplant Tourism ${ }^{66}$ that states that comprehensive reimbursement of the actual documented costs of a kidney donation does not constitute a payment but is rather part of the legitimate costs of treating the kidney recipient. The Istanbul declaration also recommends that the reimbursement should be made by the party responsible for the costs of treating the kidney recipient such as the health department of the government. The Istanbul declaration also clearly states what expenses may be reimbursed. ${ }^{67}$ It should be borne in mind that the donor has the choice to accept the reimbursement or not.

61 National Kidney Foundation "When Stopping Dialysis Treatment is Your Choice" (March 2011) http://www.nfks.org (accessed 2012-04-29).

62 Chow "NKF Fund Reimburses Five Kidney Donors" April 2010 http://www.asiaone.com (accessed 2012-04-29).

63 http://www.hpm.org (accessed on 2012-04-29).

64 Ibid.

65 S 39(1).

66 Hereinafter "the Declaration of Istanbul". South Africa is a signatory to the Declaration. See also the WHO Principle 5 which allows the reimbursement of costs concerning kidney donation. World Health Organization "WHO Guiding Principles on Human Cell, Tissue and Organ Transplantation" http://www.who.int/transplantation/Guiding_PrinciplesTransplanta tion WHA63.22en.pdf January 2010 (accessed 2012-06-18). South Africa is a member of the World Health Organization.

67 Legitimate expenses that may be reimbursed include the cost of any medical and psychological evaluations of a potential living donor; the costs incurred in arranging and effecting the pre-, peri- and post-operative phases of the kidney donation; and medical expenses incurred for post-discharge care of the donor and lastly lost income in relation to the kidney donation. 
South Africa could also establish a transplant-ethics committee to evaluate whether a donor may receive reimbursement and to what extent the reimbursement will be made. Instating a transplant-ethics committee will insure that all reimbursements are done fairly and equally. South Africa could also take a step further regarding transplant legislation by following the Iranian model of paid and regulated kidney donations.

\section{Iran and kidney donations}

In Ancient Greek times, Iran was referred to as "Persia" or "the land of Aryans". Today, Iran is a country situated in the Middle East between the Caspian Sea and the Persian Gulf and has 68 million inhabitants. ${ }^{68}$ The first kidney transplant in Iran was performed in 1967. Since this first kidneytransplant and until 1985, Iran only transplanted approximately 100 kidneys due to a lack of infrastructure available to maintain and develop a kidney transplant network in the country. ${ }^{69}$ The transplant activity was very low up until 1980, and due to this the Minister of Health decided to allow patients that were starting dialysis to travel abroad to receive a kidney transplant, which would be funded by the government. ${ }^{70}$ From 1980 to 1985 , more than 400 patients were sent to various European countries and the United States of America to receive government-funded kidney transplants. ${ }^{71}$ From 1985 to 1987, the prevalence of patients with end-stage renal failure was approximately 25000 (or 350 per one million persons) in Iran. ${ }^{72}$ In 1988, the number of patients with end-stage renal failure started to escalate drastically, and most of these patients did not have a living related donor. ${ }^{73}$ To make matters even worse, at this time Iran had no deceased-donor organ programme or any future plans for such a programme. ${ }^{74}$ At this time, the government-funded travel to overseas countries for kidney transplants was too expensive, and with this number of patients, completely unaffordable. All these circumstances led to the government-funded, regulated and compensated living, unrelated donor- renal transplantation programme ${ }^{75}$ that was adopted in $1988 .^{76}$

Ghods "Renal Transplantation in Iran" 200217 Nephrology Dialysis Transplantation 222.

69 Rupert "Paying Kidney Donors: Time to Follow Iran?" 200811 McGill Journal of Medicine 68.

70 Ghods and Savaj "Iranian Model of Paid and Regulated Living-Unrelated Kidney Donation" 20066 Clinical Journal of the American Society of Nephrology 1137.

See Ghods 200217 Nephrology Dialysis Transplantation 222.

See Ghods and Savaj 20066 Clinical Journal of the American Society of Nephrology 1137.

See Rupert 200811 McGill Journal of Medicine 68.

See Ghods and Savaj 20066 Clinical Journal of the American Society of Nephrology 1137.

Hereinafter "the Iranian model".

76 Bagheri "Compensated Kidney Donation: An Ethical Review of the Iranian Model" 200616 Kennedy Institute of Ethics Journal 270. 


\section{The Iranian model of paid kidney donations ${ }^{77}$}

Since the implementation of the Iranian model, 19609 kidney transplants have been performed. ${ }^{78}$ The Iranian model led to the establishment of the Dialysis and Transplant Patient Association. ${ }^{79}$ If a patient does not have a living, related kidney donor, or if the related kidney donor is unwilling, then he will be referred to the DATPA, and they will locate a suitable living, unrelated kidney donor for the patient. ${ }^{80}$ Volunteers that would like to donate a kidney are also referred to the DATPA. All members of the DATPA have end-stage renal failure and they receive no incentive for finding unrelated kidney donors, or for referring any recipients and donors to the transplant team. Once the kidney recipient and kidney donor have been matched, the next step is the evaluation of both the donor and recipient. The donor and recipient are both subjected to extensive clinical and psychological evaluation, as well as appropriate laboratory tests and imaging. ${ }^{81}$ During the evaluation, the transplant physician emphasizes the advantages of using a living, related donor, compared with an unrelated donor, and the scarcity of deceased-donor kidneys is also mentioned. ${ }^{82}$ All living kidney donors are further subjected to an assessment by the donor selection panel to assure that their consent is voluntary. ${ }^{83}$

The Iranian model does not leave any gap for an organ broker or agency to intervene. All transplant teams belong to university hospitals, and the government pays all the hospital expenses in relation to the kidney transplant. ${ }^{84}$ After the kidney transplant, the government provides the kidney donor with a governmental donor award of approximately $\$ 1200$, and the kidney recipients are provided with immunosuppressive drugs at a subsidized reduced rate. ${ }^{85}$ Furthermore, the majority of kidney donors also receive a rewarding gift (as arranged and defined by the DATPA) from the recipient before the kidney transplant. If the recipient is poor, the rewarding gift will be sponsored by a charitable organization, known as the Charity Foundation of Special Diseases. ${ }^{86}$ All kidney donors and recipients need to

77 It should be borne in mind that the Iranian model of paid kidney donations does not involve the buying and selling of donor kidneys. An established amount is given to the kidney donor as a rewarding gift from the government and the kidney recipient.

783421 transplants were from living, related donors, 15365 transplants were from living, unrelated donors, and 823 from deceased donors. See Ghods and Savaj 20066 Clinical Journal of the American Society of Nephrology 1137.

79 Hereinafter "DATPA"

80 See Ghods and Savaj 20066 Clinical Journal of the American Society of Nephrology 1137.

81 The European best-practice guidelines for renal transplantation and the Amsterdam Forum on the care of the live-kidney donor medical guide are being used for this purpose. See Ghods and Savaj 20066 Clinical Journal of the American Society of Nephrology 1139.

82 A transplant centre at the Shiraz University asks all kidney-transplant candidates to wait up to six months for a possible deceased kidney to become available. See Ghods and Savaj 20066 Clinical Journal of the American Society of Nephrology 1137.

83 From 1986 to 2000, the donor-selection panel consisted of nephrologists, transplant surgeons and members of nursing staff. Since 2000, the panel acts independently - a first session of the transplant nephrologists followed by a session of the members of the surgical team.

84 See Ghods 200217 Nephrology Dialysis Transplantation 224.

85 See Ghods and Savaj 20066 Clinical Journal of the American Society of Nephrology 1138.

86 See Bagheri 200616 Kennedy Institute of Ethics Journal 271. 
apply to the Association for Supporting Renal Patients (which is also a charity organization). The kidney donor needs to sign a pledge stating that he will not claim any kind of monetary reward from the recipient during the laboratory tests and after the kidney transplant. ${ }^{87}$ The kidney recipient also signs a pledge not to compensate the kidney donor directly. After the kidney transplant, a number of documents, which include the pledges, are submitted to the Charity Foundation for Special Diseases, which will then pay the kidney donor a fixed amount. ${ }^{88}$

The Iranian model also prevents any transplant tourism. Foreigners are not allowed to undergo kidney transplants from living, unrelated Iranian kidney donors, nor are they permitted to volunteer as kidney donors to unrelated Iranian recipients. ${ }^{89}$ Unfortunately, Iran has no national transplant registry (as previously mentioned, neither does South Africa) to report the short- and long-term results of all kidney transplants. However, the fact that the Iranian model has eliminated the transplant waiting list in Iran says enough.

\section{Arguments supporting the Iranian model}

Many issues that are usually associated with paid kidney donations have been prevented by the Iranian model. One of biggest problems (namely the intervening of an organ broker or organ agency) has been eliminated by the existence of the DATPA, and because the government pays for all hospital expenses in relation to the kidney transplants. ${ }^{90}$ The main criticism that is usually raised concerning paid organ donations is that if payment for kidneys is legalized then only the rich will be able to afford a kidney while the poor will have to go without. The elimination of the kidney-transplant waiting list in Iran benefits the rich and the poor. Everyone in Iran has equal access to all transplant facilities, and if a recipient is too poor to provide the kidney donor with a rewarding gift, then it is awarded by a charitable organization. ${ }^{91}$ The Iranian model had no influence whatsoever on the deceased-donor programme that was established in 2000 . In 2000 only $1,8 \%$ of all renal transplants were from deceased donors. This increased to $12 \%$ between 2004 and 2005. There are a number of reasons for the slow increase - such as infrastructural deficiencies and cultural barriers. ${ }^{92}$

One of the most important and ethical influences that the Iranian model has is the elimination of coerced living, related donors. Because of the Iranian culture, coerced living, related donors are very common. A kidney donation done by a volunteer is much more ethically acceptable than a living, related donation done with some degree of family pressure or emotional coercion. ${ }^{93}$ Furthermore, the many illegal and commercial transplants before 1988 were eliminated by the Iranian model. Prior to the

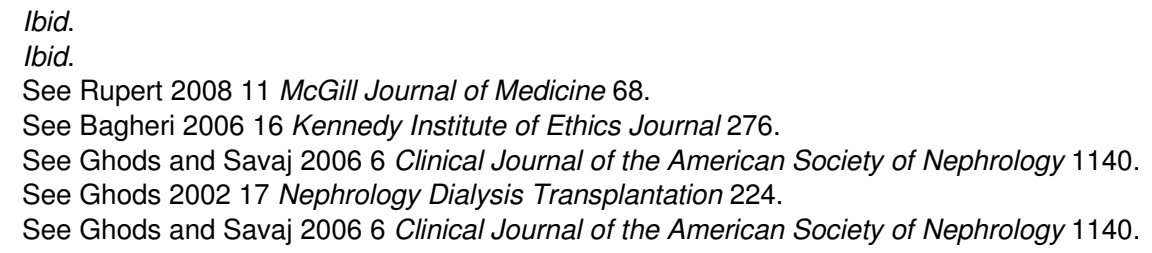


model, many kidney recipients that needed a living, unrelated kidney donor travelled to India where they received paid kidney transplants that could have a number of negative implications. ${ }^{94}$ It could be deduced that the most important influence of the Iranian model is the many patients whose death and suffering have been prevented.

\section{Arguments against the Iranian model}

According to the critics of the Iranian model, there are a number of ethical issues that should be taken into account. The critic's first and main concern is that the $\$ 1200$ supplied by the government is a fixed amount and is not enough to satisfy the majority of kidney donors. The amount supplied by the government, however, is not the only gift the kidney donor receives; he also receives the additional rewarding gift from the recipient or from a charitable organization if the recipient is financially needy. ${ }^{95}$ The critics still feel that this is not enough and that, just as war-injured veterans in each society receive legal and social items of benefits, the same should be offered to kidney donors. By providing financial incentive and social benefits by the government and eliminating the rewarding gifts, the Iranian model will function as a non-directed paid kidney-donation programme, in other words a kidney donor donates a kidney to help whomever is on the waiting list, the donor has no say in who will or will not receive the kidney. ${ }^{96}$ The possible response to this is that the Iranian model was not adopted to upgrade the socio-economic class of the kidney donors, but rather to save the lives of dying patients with end-stage renal failure. ${ }^{97}$

The issue is also raised that the increased supply of donor kidneys may cause a lowering of the strict clinical selection criteria for kidney transplantation. ${ }^{98}$ The concern with the increased supply is that the medical practitioner may recommend transplantation sooner than would usually be advised. ${ }^{99}$ Further ethical issues that exist are that public education and the establishment of an Iranian donor registry is necessary. ${ }^{100}$ None of these issues is a serious ethical issue. The Iranian model may involve payment for a kidney, but all aspects of the model are strictly enforced by the various transplant teams and the Iranian Society of Organ Transplantations. ${ }^{101}$ Other strategies that are often cited by various opponents of paid organ donations, such as presumed consent, non-heart-beating deceased donors and ABOincompatible paired-exchange kidney transplants, do not have the potential to eliminate or even alleviate the renal waiting lists, but the Iranian model could accomplish this. ${ }^{102}$

94 See Ghods and Savaj 20066 Clinical Journal of the American Society of Nephrology 1141.

95 See Bagheri 200616 Kennedy Institute of Ethics Journal 279.

96 See Ghods and Savaj 20066 Clinical Journal of the American Society of Nephrology 1141.

97 Ghods, Savaj and Khosravani "Adverse Effect of a Controlled Living Unrelated Donor Renal Transplant Program on Living Related and Cadaveric Kidney Donation" 200133 Transplant Proceedings 2627.

98 See Bagheri 200616 Kennedy Institute of Ethics Journal 277.

99 Ibid.

100 See Ghods 200217 Nephrology Dialysis Transplantation 223.

101 See Ghods and Savaj 20066 Clinical Journal of the American Society of Nephrology 1142.

102 See Ghods and Savaj 20066 Clinical Journal of the American Society of Nephrology 1143. 
If South Africa should ever legalize the selling of donor kidneys, the Iranian model will be the perfect model to incorporate. South Africa and Iran have a lot of rural areas and illiterate persons. The only difference between these two countries is that Iran does not have a bill of rights or any humanrights instruments, but a DATPA could also be established to locate suitable living, unrelated kidney donors and to accommodate any volunteers that wish to donate their kidneys. This association could also be subjected to strictly enforced ethical control. This type of model in South Africa could also eliminate the majority of illegal organ-trading incidents which are steadily increasing in South Africa. If such a model is adopted in South Africa, the poor will also stand a chance to receive a donor kidney. More patients will receive kidney transplants, thus leading to more lives being saved and a decrease in the number of patients that receive renal dialysis will take place; consequently, giving more patients the chance to receive renal dialysis and live long enough to receive a donor kidney.

\section{CONCLUSION}

As everything in the medical world is regulated by laws, the same is applicable to kidney transplants. Kidney transplants in South Africa are mainly regulated by chapter 8 of the National Health Act but, as Crespi states:

"Many deaths from organ failure are no longer the result of an inexorable fate that we must accept, but occur in the modern world only as the unintended consequence of a flawed regime that can be changed."

Only the law can help with the dire need concerning the availability of kidneys for transplants. Taking this a step further, the law can develop and make the accessibility of kidneys easier by allowing the buying and selling of kidneys in a regulated environment. ${ }^{104}$

South Africa and Singapore have the same legal stipulation that a donor may be reimbursed for costs incurred with the donation. Singapore has gone further and implemented it, South Africa is not there yet. It would be worthwhile following their example, but South Africa could also follow the Iranian model. The end result should never be overlooked - to help desperate people in need of a transplant.

103 Slabbert "Handeldryf met Menslike Organe en Weefsel vir Oorplantingsdoeleindes" LLD thesis (University of the Free State 2002).

104 See Slabbert and Oosthuizen 200728 Obiter 45. 